RESEARCH NOTE

\title{
Controlled deterioration test for evaluation of sunn hemp seed vigor ${ }^{1}$
}

\author{
Arthur Batoqui Costa e Silva², Ícaro Monteiro Galvão ${ }^{3 *}$, Rafael Marani Barbosa ${ }^{3}$, \\ Clíssia Barboza da Silva², Roberval Daiton Vieira ${ }^{2}$
}

\begin{abstract}
The controlled deterioration test is efficient for seed vigor evaluation of several species. However, the procedures conditions are incipient, especially in respect to tropical forages such as sunn hemp, which still does not have a standardized procedure. The objective of this research was to adjust the procedures for a controlled deterioration test in Crotalaria juncea L. seeds. For this, five commercial seed lots were evaluated for water content and initial physiological potential (germination test, first germination count, germination speed index, saturated salt accelerated aging with $\mathrm{NaCl}$, electrical conductivity and seedling field emergence). For controlled deterioration test, the initial seed moisture content was adjusted to 18,21 and $24 \%$ and, subsequently, the samples were exposed at $45^{\circ} \mathrm{C}$ during 24 hours. Seed germination test was conducted with the use of sand as substrate. Evaluations were performed on the fourth, fifth and sixth day after sowing. The controlled deterioration test for sunn hemp seeds should be performed with $24 \%$ seed moisture content, at $45{ }^{\circ} \mathrm{C}$ during 24 hours, and the test evaluation on the fourth day after sowing.
\end{abstract}

Index terms: Crotalaria juncea L., germination, physiological potential, test standardization.

\section{Teste de deterioração controlada para avaliação do vigor de sementes de crotalária}

RESUMO - O teste de deterioração controlada é eficiente para avaliar o vigor de sementes de diversas espécies. No entanto, as condições para realização desse teste são incipientes, principalmente quando se trata de forrageiras tropicais, como é o caso da crotalária, cujas informações sobre a adequação do teste ainda são escassas. Assim, o objetivo deste trabalho foi adequar os procedimentos para a execução do teste de deterioração controlada para sementes de Crotalaria juncea L. Para tanto, cinco lotes de sementes comerciais foram avaliados quanto ao teor de água e potencial fisiológico inicial (teste de germinação, primeira contagem, índice de velocidade de germinação, envelhecimento acelerado com solução saturada de $\mathrm{NaCl}$, condutividade elétrica e emergência de plântulas em campo). Para o teste de deterioração controlada, o teor de água inicial das sementes foi ajustado para $18,21 \mathrm{e} 24 \% \mathrm{e}$, posteriormente, as amostras foram expostas a $45{ }^{\circ} \mathrm{C}$ durante 24 horas, postas para germinar entre areia, e avaliadas aos quarto, quinto e sexto dias após a semeadura. $\mathrm{O}$ teste de deterioração controlada em crotalária deve ser conduzido com sementes contendo $24 \%$ de teor de água, a $45^{\circ} \mathrm{C}$, durante 24 horas e a leitura realizada aos quatro dias após a semeadura.

Termos para indexação: Crotalaria juncea L., germinação, potencial fisiológico, padronização de teste.

\section{Introduction}

Sunn hemp (Crotalaria juncea L.) also known as brown hemp, Indian hemp or Madras hemp is a forage legume used as green manure, which has a high potential for biomass production in crop rotation or intercropping systems, promoting improvements in the chemical, physical and

${ }^{1}$ Submitted on 7/9/2015. Accepted for publication on 9/21/2015.

${ }^{2}$ Departamento de Produção Vegetal, Universidade Estadual Paulista, 14884900 - Jaboticabal, SP, Brasil. biological soil properties, and thus, becoming an important mechanism for recovery of degraded areas (Silva et al., 2012).

The use of high quality seeds is essential for implementation of uniform fields. Rapid and vigorous seedling establishment in the field are the keys factors to ensure the economic viability and sustainability in sunn hemp rotation and intercropping systems.

${ }^{3}$ Departamento de Ciências Agrárias e Ambientais, Universidade Estadual de Santa Cruz, 45662-900 - Ilhéus, BA, Brasil.

*Corresponding author $<$ icaro.monteiro@hotmail.com> 
Officially, only the germination test is required to attest the physiological potential of seed lots. However, the germination test is conducted under favorable environmental conditions such as oxygen, temperature and water availability, and sometimes, does not reflect the real seedling performance in the field. On the other hand, seed vigor tests are able to complement the determination of seed physiological potential because they can provide more sensitive information about this factor (Baalbaki et al., 2009).

Seed vigor can be defined as the set of characteristics that determine the ability of a commercial seed lot of acceptable germination to have a rapid and uniform seedling emergence under widely varying environmental conditions (Tekrony, 2003). In face of this, various methods have been developed for a safe evaluation of seed vigor.

Procedures of vigor testing based on stress tolerance have been used to determine the seed performance in the field (Marcos-Filho, 2015). High temperature and relative humidity can accelerate the seed deterioration process, and consequently, the seed vigor. Thus, the controlled deterioration test demonstrates to be promising to identify seed lots with different vigor levels. Because of its simplicity and efficiency, this test has drawn the attention of many seed technologists (Mendonça et al., 2003). Furthermore, the controlled deterioration test stands out due to better control over seed moisture content $\mathrm{(Hu}$ et al., 2012; Wang et al., 2015), differently of the accelerated aging test, where the seed moisture content may vary and can lead to inconsistent results (Santos et al., 2003).

The controlled deterioration test is recommended for brassica seeds (ISTA, 2014), and widely used for various seed crops, including bean (Santos et al., 2003), peanut (Rossetto et al., 2004), melon (Mavi and Demir, 2007), cotton (Dutra and Medeiros-Filho, 2008), maize (Zucareli et al., 2011), beet (Silva and Vieira, 2012), coriander (Torres et al., 2012), scarlet eggplant (Lopes et al., 2012), soybean (Cabral et al., 2012), eggplant (Lopes et al., 2013), forage turnip (Morais and Rossetto, 2013) and okra (Torres et al., 2013). However, for sunn hemp seeds, studies about seed vigor using the controlled deterioration test are still limited.

Therefore, the objective of this research was to adjust procedures for implementing of the controlled deterioration test in Crotalaria juncea L. seeds.

\section{Material and Methods}

The experiment was conducted at the Seed Analysis Laboratory of Sao Paulo State University (UNESP) of the Plant Production Department, Jaboticabal Campus, SP, Brazil, using five lots of sunn hemp seeds. For purposes of comparison and differentiation of the seed physiological potential, seeds were submitted to initial moisture content determination as well as evaluations of germination and vigor.

Seed moisture content was obtained by the oven method at $105 \pm 3{ }^{\circ} \mathrm{C}$ for 24 hours (Brasil, 2009), with two subsamples of 25 seeds for each lot, and the data expressed as a percentage (fresh weight basis).

Germination test was conducted with four replications of 50 seeds distributed in plastic boxes containing moist sand with $60 \%$ of maximum water holding capacity. Thereafter, boxes were maintained in a growth chamber at $25{ }^{\circ} \mathrm{C}$ and an eight-hour photoperiod. The evaluations were performed at four (first germination count) (Nakagawa, 1999), and ten days after sowing (final germination count) (Brasil, 2009).

Germination speed index (GSI) was obtained by the daily counting of emerged seedlings (cotyledons surpassing the substrate level). GSI was obtained according to the formula proposed by Maguire (1962).

For electrical conductivity, four replications of 50 seeds were weighed with an accuracy of $0.01 \mathrm{~g}$, and then placed in plastic cups $(200 \mathrm{~mL})$ containing $75 \mathrm{~mL}$ of deionized water. The containers were then kept at $25{ }^{\circ} \mathrm{C}$ for eight hours. The electrical conductivity of the solution was measured by conductivity meter and the results were expressed in relation to the weight $\left(\mu \mathrm{S} . \mathrm{cm}^{-1} \cdot \mathrm{g}^{-1}\right)$ (Silva et al., 2012).

The saturated salt accelerated aging (SSAA) was carried out in a single layer on a stainless steel mesh inside transparent plastic boxes $(11 \times 11 \times 3.5 \mathrm{~cm})$, containing $40 \mathrm{~mL}$ of a saturated solution of $\mathrm{NaCl}(40 \mathrm{~g} / 100 \mathrm{~mL}$ of water). The boxes were covered and kept in aging chambers at $41{ }^{\circ} \mathrm{C}$ for 96 hours (Silva et al., 2012). After the aging treatment, seeds were set to germinate following the methodology described for germination test, and assessment was carried out on the fourth day after sowing.

For seedling field emergence, four replications of 50 seeds were sown in $2 \mathrm{~m}$ long rows with $0.4 \mathrm{~m}$ between rows. Evaluations were made 14 days after sowing and the results were expressed as a percentage of emerged seedlings (Nakagawa, 1999).

After initial characterization of physiological potential of the seed lots, studies for standardization of methodologies were performed to the controlled deterioration test. Initially, seed moisture content was adjusted to three levels $(18,21$ and $24 \%$ ) by wet atmosphere method (Rossetto et al., 1995) using transparent plastic boxes. Then, seeds were kept in a bainmarie at $45^{\circ} \mathrm{C}$ for 24 hours. After this period, seeds were put to germinate in sand substrate. Data were recorded at four, five and six days after sowing.

The results from each test were analyzed by analysis 
of variance in a completely randomized design. For the controlled deterioration test, the treatments were arranged in a $5 \times 3$ factorial scheme (five seed lots $\mathrm{x}$ three seed moisture content levels), separately for each evaluation period. Data were tested for normality and homogeneity of variances and then subjected to analysis of variance. Means were compared by Tukey's test ( $\mathrm{p} \leq 0.05)$ (Banzatto and Kronka, 2008).

\section{Results and Discussion}

All seed lots were homogeneous regarding to the initial moisture content, varying between 10.1 and $13.2 \%$ (Table 1). This small variation provides greater reliability in assessing vigor by the tests, since any difference noticed between the seed lots is attributed to their physiological characteristic and not due to the discrepant values in the seed moisture content.

The germination values of all the lots were acceptable for the commercialization of sunn hemp seeds, which is fixed at $60 \%$ by the Brazilian legislation (Brasil, 2008). The seed lots also presented similar germination, one of the prerequirements for the application of vigor tests.

Lots showed differences in their physiological potentials, although the germination test, first germination count and germination speed index showed no differences (Table 1). Despite this, the electrical conductivity, saturated salt accelerated aging and the seedling field emergence were sufficient to stratify seed lots at different vigor levels. Lot 1 had low vigor, while lots 4 and 5 were the most vigorous.

Table 1. Initial seed moisture content (MC), germination (GE), first germination count (FC), germination speed index (GSI), electrical conductivity (EC), saturated salt accelerated aging (SSAA) and seedling field emergence (SFE) of five sunn hemp seed lots.

\begin{tabular}{|c|c|c|c|c|c|c|c|}
\hline \multirow{2}{*}{ Lots } & $\mathrm{MC}$ & GE & FC & GSI & $\mathrm{EC}$ & SSAA & SFE \\
\hline & \multicolumn{4}{|c|}{ 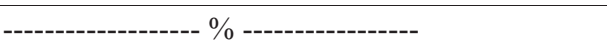 } & $\mu \mathrm{S} . \mathrm{cm}^{-1} \cdot \mathrm{g}^{-1}$ & \multicolumn{2}{|c|}{-----------\% --------- } \\
\hline 1 & 13.2 & $77 a^{*}$ & $70 \mathrm{a}$ & $9.1 \mathrm{a}$ & $108 \mathrm{c}$ & $51 \mathrm{c}$ & $65 \mathrm{~b}$ \\
\hline 2 & 14.2 & $79 \mathrm{a}$ & $76 \mathrm{a}$ & $9.7 \mathrm{a}$ & $99 \mathrm{~b}$ & $60 \mathrm{~b}$ & $66 \mathrm{~b}$ \\
\hline 3 & 13.8 & $80 \mathrm{a}$ & $78 \mathrm{a}$ & $9.9 \mathrm{a}$ & $92 \mathrm{ab}$ & $63 \mathrm{~b}$ & $68 \mathrm{~b}$ \\
\hline 4 & 10.4 & $83 \mathrm{a}$ & $80 \mathrm{a}$ & $10.2 \mathrm{a}$ & $87 \mathrm{a}$ & $70 \mathrm{~b}$ & $70 \mathrm{ab}$ \\
\hline 5 & 10.1 & $79 \mathrm{a}$ & $85 \mathrm{a}$ & $10.7 \mathrm{a}$ & $81 \mathrm{a}$ & $72 \mathrm{a}$ & $75 \mathrm{a}$ \\
\hline $\operatorname{LSD}(5 \%)$ & - & 22.4 & 18.7 & 2.6 & 7.9 & 6.5 & 5.1 \\
\hline $\mathrm{CV}(\%)$ & - & 10.5 & 11.4 & 10.3 & 12.7 & 9.8 & 11.5 \\
\hline
\end{tabular}

*Means followed by the same letter do not differ at $5 \%$ by Tukey's test.

The controlled deterioration test was efficient in highlighting lots with low and high vigor, according to the classification indicated by electrical conductivity and saturated salt accelerated aging tests as well as seedling field emergence. According to specific procedures in the controlled deterioration test with $24 \%$ seed moisture content, the lot 1 also showed low vigor.

Regarding the seed performance after running test, the $18 \%$ seed moisture content had no effect on seed physiological behavior, because there was no separation of lots into vigor classes (Table 2). Similarly, in okra seeds, the controlled deterioration test also showed no sufficient sensitivity to evaluate the seed physiological potential with $18 \%$ seed moisture content (Torres et al., 2013).

The best separation of lots occurred in seed lots with $24 \%$ moisture content, because promoted comparable results with other tests which were used for physiological potential characterization, and also showed accordance with procedures for testing in seeds from other species (Table 2). The $24 \%$ seed moisture content was also the most suitable for controlled deterioration test in cotton
(Dutra and Medeiros-Filho, 2008), scarlet eggplant (Lopes et al., 2012), and okra (Torres et al., 2013). On the other hand, the $20 \%$ seed moisture content was suitable for bean (Santos et al., 2003), melon (Mavi and Demir, 2007), and cauliflower (Kikuti and Marcos-Filho, 2008), whereas in peanut seeds, $15 \%$ moisture content was the most appropriate treatment (Rossetto et al., 2004).

There was a reduction in the controlled deterioration test results while seed moisture content increased (18, 21 and 24\%). Seeds with higher moisture content have been more susceptible to unfavorable environmental conditions, so that, a higher moisture content was followed by a lower ability to the seeds to tolerate these stresses, which can affect the seed performance due to excessive intensification of metabolic activity.

The basic objective of a seed vigor test is to identify physiological differences among lots of marketable seeds with greater sensitivity compared to the germination test (Marcos-Filho, 2015). In addition, vigor tests should meet the requirements of objectivity, simplicity, low cost and 
reproducibility as well as obtaining rapid results. Thus, the four-day period for the controlled deterioration test in sunn hemp seeds can be considered the most promising (Table 2), since the vigor rating among lots was the same to the indicated during initial physiological potential evaluation.

Table 2. Controlled deterioration of five sunn hemp seed lots due to the seed moisture content (MC) and evaluation periods (days).

\begin{tabular}{|c|c|c|c|c|}
\hline \multirow{3}{*}{ Periods } & \multirow{3}{*}{ Lots } & \multicolumn{3}{|c|}{$\mathrm{MC}$} \\
\hline & & $18 \%$ & $21 \%$ & $24 \%$ \\
\hline & & \multicolumn{3}{|c|}{-------------- \% \% -------------- } \\
\hline \multirow{5}{*}{4 days } & 1 & $66 \mathrm{aA}^{*}$ & 76 abA & $65 \mathrm{bA}$ \\
\hline & 2 & $71 \mathrm{aA}$ & $65 \mathrm{bA}$ & $70 \mathrm{abA}$ \\
\hline & 3 & $78 \mathrm{aA}$ & $73 \mathrm{abAB}$ & $65 \mathrm{bB}$ \\
\hline & 4 & $75 \mathrm{aA}$ & $73 \mathrm{abA}$ & $65 \mathrm{bA}$ \\
\hline & 5 & $78 \mathrm{aA}$ & $82 \mathrm{aA}$ & $83 \mathrm{aA}$ \\
\hline & CV (\%) & \multicolumn{3}{|c|}{8.8} \\
\hline \multirow{6}{*}{5 days } & 1 & $70 \mathrm{aA}$ & $77 \mathrm{abA}$ & $69 \mathrm{bA}$ \\
\hline & 2 & $78 \mathrm{aA}$ & $70 \mathrm{bA}$ & $73 \mathrm{abA}$ \\
\hline & 3 & $79 \mathrm{aA}$ & $75 \mathrm{abAB}$ & $67 \mathrm{bB}$ \\
\hline & 4 & $79 \mathrm{aA}$ & $79 \mathrm{abA}$ & $68 \mathrm{bB}$ \\
\hline & 5 & $79 \mathrm{aA}$ & $83 \mathrm{aA}$ & $83 \mathrm{aA}$ \\
\hline & $\mathrm{CV}(\%)$ & \multicolumn{3}{|c|}{8.0} \\
\hline \multirow{6}{*}{6 days } & 1 & $70 \mathrm{aA}$ & $77 \mathrm{abA}$ & $69 \mathrm{bA}$ \\
\hline & 2 & $70 \mathrm{aA}$ & $70 \mathrm{bA}$ & $73 \mathrm{abA}$ \\
\hline & 3 & $80 \mathrm{aA}$ & $75 \mathrm{abAB}$ & $68 \mathrm{bB}$ \\
\hline & 4 & $80 \mathrm{aA}$ & $80 \mathrm{abAb}$ & $70 \mathrm{bB}$ \\
\hline & 5 & $80 \mathrm{aA}$ & $84 \mathrm{aA}$ & $84 \mathrm{aA}$ \\
\hline & CV (\%) & \multicolumn{3}{|c|}{7.8} \\
\hline
\end{tabular}

*Means followed by the same lowercase letter in the column and uppercase in the row do not differ at $5 \%$ by Tukey's test.

In researches about procedures standardization for seed vigor evaluation, studies have showed that during the test, a reduction in the period of time, up to certain limits seems to be more advantageous considering the speed of obtaining results. The proposal for evaluation at four days was confirmed in this study, being in agreement with recommendation, which suggests that the evaluation period of the controlled deterioration test should be the same of the first germination count. The decision to use the controlled deterioration test in seed quality control programs depends on the accessibility of the method for analysts as well as the obtaining quick results associated with data obtained during seedling field emergence. Vigor tests based on stress, such as controlled deterioration test can provide important information about the seed physiological potential when used with other tests, which helps during decision-making for seed storing and sowing (Barbosa et al., 2013).

\section{Conclusions}

The controlled deterioration test in Crotalaria juncea seeds should be carried out with $24 \%$ moisture content at $45{ }^{\circ} \mathrm{C}$ for 24 hours and the evaluation on the fourth day after sowing.

\section{References}

BAALBAKI, R.Z.; ELIAS, S.; MARCOS-FILHO, J.; McDONALD, M.B. Seed vigor testing handbook. Ithaca, New York: AOSA, 2009. 346p.

BANZATTO, D.A.; KRONKA, S.N. Experimentação agrícola. 4.ed. Jaboticabal: FUNEP. 2008. 237 p.

BARBOSA, R.M.; VIEIRA, B.G.T.L.; FERRAUDO, A.S.; CORÁ, J.E.; VIEIRA, R.D. Discrimination of soybean seed lots by multivariate exploratory techniques. Journal of Seed Science, v.35, n.3, p.302-310, 2013. http://dx.doi.org/10.1590/S2317-15372013000300005

BRASIL. Ministério da Agricultura, Pecuária e Abastecimento. Regras para análise de sementes. Ministério da Agricultura, Pecuária e Abastecimento. Secretaria de Defesa Agropecuária. Brasília: MAPA/ACS, 2009. 395p. http:// www.agricultura.gov.br/arq editor/file/2946 regras analise sementes.pdf

BRASIL. Ministério da Agricultura, Pecuária e Abastecimento. Instrução Normativa n. 30, de 21 de maio de 2008. (Estabelecer normas e padrões para produção e comercialização de sementes de espécies forrageiras de clima tropical). Diário Oficial da União, Poder Executivo, Brasília, DF, Anexo IV.: http://www.adagri.ce.gov.br/Docs/legislacao_vegetal/IN_30_ de_21.05.2008.pdf

CABRAL, Y.C.F.; ÁVILA, M.R.; ORTIZ, T.A. Desempenho de lotes de sementes de soja submetidos ao teste deterioração controlada. Journal of Agronomic Sciences, v.1, n.1, p.45-57, 2012. http://www.dca.uem.br/ V1N1/05-Yara.pdf

DUTRA, A.S.; MEDEIROS-FILHO, S. Teste de deterioração controlada na determinação do vigor em sementes de algodão. Revista Brasileira de Sementes, v.30, n.1, p.19-23, 2008. http://dx.doi.org/10.1590/S010131222008000100003

HU, D.; MA, G.; WANG, Q.; YAO, J.; WANG, Y.; PRITCHARD, H.W.; WANG, X. Spatial and temporal nature of reactive oxygen species production and programmed cell death in elm (Ulmus pumila $\mathrm{L}$.) seeds during controlled deterioration. Plant Cell Environment, v.35, n.11, p.2045-2059, 2012. http:// www.ncbi.nlm.nih.gov/pubmed/22582978

ISTA. International Seed Testing Association. Seed Vigour Testing. International Rules for Seed Testing, Zurich, Switzerland, 2014.

KIKUTI, A.L.P.; MARCOS-FILHO, J. Physiological potential of cauliflower seeds. Scientia Agricola, v.65, n.4, p.374-380, 2008. http://dx.doi org/10.1590/S0103-90162008000400008

LOPES, M.M.; BARBOSA, R.M.; VIEIRA, R.D. Methods for evaluating the physiological potential of scarlet eggplant (Solanum aethiopicum) seeds. Seed Science and Technology, v.40, n.1, p.86-94, 2012. http://dx.doi. org/10.15258/sst.2012.40.1.09

LOPES, M.M.; SILVA, C.B.; VIEIRA, R.D. Physiological potential of eggplant seeds. Journal of Seed Science, v.35, n.2, p.225-230, 2013. http:// dx.doi.org/10.1590/S2317-15372013000200012 
MAGUIRE, J.D. Speed of germination aid in selection and evaluation for seedling emergence and vigor. Crop Science, v.2, n.2, p.176-177, 1962.

MARCOS-FILHO, J. Seed vigor testing: an overview of the past, present and future perspective. Scientia Agricola, v.72, n.4, p.363-374, 2015. http:// dx.doi.org/10.1590/0103-9016-2015-0007

MAVI, K.; DEMIR, I. Controlled deterioration and accelerated aging tests predict relative seedling emergence potential of melon seed lots. Hortscience, v.42, n.6, p.1431-1435, 2007. www.mku.edu.tr/getblogfile.php?keyid=142

MENDONÇA, E.A.F.; RAMOS, N.P.; FESSEL, S.A. Adequação da metodologia do teste de deterioração controlada para sementes de brócolis (Brassica oleracea L. var. italica). Revista Brasileira de Sementes, v.25, n.1, p.18-24, 2003. http://dx.doi.org/10.1590/S0101-31222003000100004

MORAIS, C.S.B.; ROSSETTO, C.A.V. Testes de deterioração controlada e envelhecimento acelerado para avaliação do vigor em nabo forrageiro. Revista Ciência Agronômica, v.44, n.4, p.703-713, 2013. http://dx.doi. org/10.1590/S1806-66902013000400006

NAKAGAWA, J. Testes de vigor baseados no desempenho das plântulas. In: KRZYZANOWSKI, F.C.; VIEIRA, R.D.; FRANÇA-NETO, J.B. (Ed.). Vigor de sementes: conceitos e testes. Londrina: ABRATES, 1999. cap. 2, p. 1-24.

ROSSETTO, C.A.V.; FERNANDEZ, E.M.; MARCOS-FILHO, J. Metodologias de ajuste do grau de umidade e comportamento das sementes de soja no teste de germinação. Revista Brasileira de Sementes, v.17, n.2, p.171-178, 1995. http://www.scielo.br/scielo.php?script=sci_ nlinks\&ref $=000086 \&$ pid $=$ S0103-8478201200070000400015\&lng=en

ROSSETTO, C.A.V.; LIMA, T.M.; GUIMARÃES, E.C. Envelhecimento acelerado e deterioração controlada em sementes de amendoim. Pesquisa Agropecuária Brasileira, v.39, n.8, p.795-801, 2004. http://dx.doi. org/10.1590/S0100-204X2004000800010

SANTOS, C.M.R.; MENEZES, N.L.; VILLELA, F.A. Teste de deterioração controlada para avaliação do vigor de sementes de feijão. Revista Brasileira de Sementes, v.25, n.2, p.28-35, 2003. http://dx.doi.org/10.1590/S010131222003000400005
SILVA, C.B.; LOPES, M.M.; MARCOS-FILHO, J.; VIEIRA, R.D. Automated system of seedling image analysis (SVIS) and electrical conductivity to assess sun hemp seed vigor. Revista Brasileira de Sementes, v.34, n.1, p.5560, 2012. http://dx.doi.org/10.1590/S0101-31222012000100007

SILVA, J.B.; VIEIRA, R.D. Deterioração controlada para avaliar o potencial fisiológico de sementes de beterraba. Horticultura Brasileira, v.30, n.3, p.379-384, 2012. http://dx.doi.org/10.1590/S0102-05362012000300004

TEKRONY, D.M. Precision is an essential component in seed vigour testing Seed Science and Technology, v.31, n.2, p.435-447, 2003. http://dx.doi. org/10.15258/sst.2003.31.2.20

TORRES, S.B.; DANTAS, A.H.; PEREIRA, M.F.S.; BENEDITO, C.P.; SILVA, F.H.A. Deterioração controlada em sementes de coentro. Revista Brasileira de Sementes, v.34, n.2, p.319-326, 2012. http://dx.doi.org/10.1590/ S0101-31222012000200018

TORRES, S.B.; GOMES, M.D.A.; SILVA, F.G.; BENEDITO, C.P.; PEREIRA, F.E.C.B. Controlled deterioration to evaluate okra seed vigor. Horticultura Brasileira, v.31, n.2, p.317-321, 2013. http://dx.doi.org/10.1590/ S0102-05362013000200023

WANG, Y.; YING, L.; XUE, H.; PRITCHARD, H.W.; WANG, X. Reactive oxygen species-provoked mitochondria-dependent cell death during ageing of elm (Ulmus pumila L.) seeds. The Plant Journal, v.81, n. 1, 438-452, 2015. http://www.ncbi.nlm.nih.gov/pubmed/25439659

ZUCARELI, C.; CAVARIANI, C.; SBRUSSI, C.A.G.; NAKAGAWA, J Teste de deterioração controlada na avaliação do vigor de sementes de milho. Revista Brasileira de Sementes, v.33, n.4, p.732-742, 2011. http://dx.doi. org/10.1590/S0101-31222011000400015 